\title{
Effect of Atorvastatin Treatment on Vascular Aterogenic Factors (Lipid Profiles and VCAM-1) in Patient Diabetes with Dyslipidemia
}

\author{
Asri Wido Mukti ${ }^{1}$, Budi Suprapti ${ }^{1}$, and Sony Wibisono ${ }^{2}$
}

1. Magister of Clinical Pharmacy, Universitas Airlangga, Surabaya, Indonesia

2. Division Endocrinology and Metabolism - Department of Internal Medicine, Dr. Soetomo Teaching Hospital School ofMedicine Airlangga University

\begin{abstract}
Info Article
Submitted: 23-04-2018

Revised: 18-03-2019

Accepted: 09-04-2019

*Corresponding author Asri Wido Mukti

Email

ninoasri@gmail.com

ABSTRACT

To analyze effectiveness of atorvastatin $20 \mathrm{mg}$ on lipid profiles and adhesion molecule VCAM-1 in patient with diabetes dyslipidemia. An observational prospective cohort study was conducted from November 2016 to March 2017. Patients who fulfilled the inclusion criteria were taken twice for their lipid profiles and VCAM-1 measurements (before initiation of study and after 6 weeks treatment of atorvastatin $20 \mathrm{mg}$ ). There were 13 patients who met the inclusion criteria. The results of 13 patients showed that after 6 weeks of atorvastatin therapy, there was a $28 \%$ decrease in total cholesterol $(\mathrm{t} 0=223.77 \pm 49.69, \mathrm{t} 1=160.92 \pm 24.69), 39 \% \mathrm{LDL}$ decrease ( $\mathrm{t} 0=152.59 \pm 44.25, \mathrm{t} 1=93 \pm 21.44)$, a decrease in TG $38.6 \%$ ( $\mathrm{t} 0=200.85 \pm 101.53, \quad \mathrm{t} 1=123.30 \pm 62.77)$ and a statistically significant decrease in VCAM-1 7.47\% ( $\mathrm{t} 0=729.59 \pm 208.06, \mathrm{t} 1=675.06 \pm 182.88)$. The results of the correlation test between total cholesterol and VCAM-1 $(\mathrm{p}=0.185, \mathrm{r}=0.268)$, LDL and VCAM- $1(\mathrm{p}=0.127, \mathrm{r}=0.307)$, TG and VCAM-1 $(\mathrm{p}=0.198, \mathrm{r}=0.261$ ) showed no correlation. Based on the results of the study, it can be concluded that atorvastatin therapy can provide improvements in atherogenic factors such as decreased lipid profile and VCAM-1, and there was no correlation between lipid profile and VCAM-1 in type 2 DM patients with dyslipidemia.
\end{abstract}

Keywords : Atorvastatin, Adhesion molecules, Diabetes mellitus, , dyslipidemia, VCAM-1.

\section{INTRODUCTION}

Diabetes mellitus (DM) is a metabolic disorder disease characterized by hyperglycemia (Triplitt et al., 2014). The most common lipid pattern in people with type 2 diabetes consists of hypertriglyceridemia (hyper-TG), low high-density lipoprotein cholesterol (HDL-C), and relatively normal plasma concentrations of low-density lipoprotein cholesterol (LDL-C) (Hegele et al., 2013). The condition of hyperglycemia and increased free fatty acids can cause endothelial damage, endothelial become more permeable, presence of reactive oxygen species (ROS), and increase adhesion molecules (George and Lyon, 2010). One of the adhesion molecules which has increased is VCAM-1. VCAM- 1 is a member of the protein of immunoglobulin superfamily which is the framework for the migration of leukocytes to subendothelial space. If this leukocyte migration not prevented will cause monocytes to maturate into macrophages and form foam cell and fatty streak that will cause atherosclerosis (Wang and Huo, 2010).

Levels of soluble adhesion molecules have been shown to correlate with various cardiovascular risk factors including hypercholesterolemia and or hypertriglyceride, decreased HDL, hypertension, DM, and smoking. In two prospective studies of patients with type 2 diabetes, VCAM-1 became a strong predictor of cardiovascular mortality. VCAM-1 levels are also significantly associated with intima-media thickness, an index of early atherosclerotic (Wang and Huo, 2010).

Atorvastatin is a class of lipid-lowering agent, HMG CoA reductase inhibitor. HMG CoA is a precursor of mevalonate formation which is a synthesis of cholesterol (Malloy and Kane, 2012). 
Atorvastatin also has a pleiotropic effect that can inhibit inflammation by inhibition of leukocytes by decreasing the expression of adhesion molecules, therefore the aim of this study was to analyze the effect of atorvastatin on lipid profile and pleiotropic effects as inhibition of inflammation.

\section{MATERIAL AND METHODS}

This study conducted a prospective observational design from November 2016 to March 2017 was approved by Ethics Committee of the the faculty of Medicine Airlangga University Surabaya. We included pastients aged 35-79 years who were diagnosed with diabetic dyslipidemia, HbA1c 8-13\%, lipid profiles during initiation of LDL therapy $>100 \mathrm{mg} / \mathrm{dL}$ and $/$ or $\mathrm{TG}>150 \mathrm{mg} / \mathrm{dL}$, free or at least 2-3 weeks after acute inflammation, and have not received atorvastatin therapy previously. Patients with elevated liver function tests $(>3 \mathrm{x}$ normal values), patients with severe renal failure, patients with nephrotic syndrome with dyslipidemia, and patients taking progestin hormones, corticosteroids, and antiretroviral drugs (protease inhibitor class) were excluded from the study. Blood measurements were performed on lipid profiles (total cholesterol, LDL, and TG) and VCAM-1 before therapy of atorvastatin $20 \mathrm{mg}$ and after 6 weeks therapy. VCAM-1 were measured with ELISA method.

Analysis data started with normality test with Saphiro Wilk test. A comparative hypothesis test was performed to determined the differences of lipid profiles and VCAM- 1 before therapy $\left(t_{0}\right)$ and after therapy $\left(\mathrm{t}_{1}\right)$ with paired sample T-test and Wilcoxon test. In addition, a correlation test was performed to determine the correlation between lipid profile and VCAM-1 by using spearman correlation test.

\section{RESULTS AND DISCUSSION}

The number of male and female patients is almost equal with the most age range in the middle age range (46-59 years) (Table I). Based on research conducted by Mihardja et al in Indonesia also shows that the prevalence of DM increases with age with the highest age range 45-55 years (Mihardja et al., 2014). HbA1c levels indicate uncontrolled sugar ranges (8-13\%) and most patients are overweight (BMI 25-18kg/m2). Overweight and obesity are the most potent risk factors for DM (WHO, 2016). Three patients had comorbidities of hypertension and two patients with CHD. In a study conducted by Lastra (et al.) also found that hypertension was found in more than $50 \%$ of patients with DM and contributed significantly to micro and macrovascular complications in DM. The risk factor for cardiovascular disease is 4 times higher in DM patients with hypertension (Lastra et al., 2014).

The NCEP-ATP III guidelines divided LDL and TG levels within the range that can be used as indicative references when lipid-lowering therapy may be given. When TG levels are within a borderline high range, LDL-C is the main therapeutic target. Similarly, when TG levels are in the high range, LDL-C is still a major therapeutic target. Add lipid-lowering drugs such as fibrates to help reduce them. Individuals with very high TG levels $(>500 \mathrm{mg} / \mathrm{dL})$ are at risk for acute pancreatitis, therefore the primary target is the reduction of TG first with a low-fat diet, weight management and physical activity, and the use of fibrates or nicotinic acid. If TG levels reach $<500$ $\mathrm{mg} / \mathrm{dl}$ then it can be replaced again with LDLlowering therapy (NCEPATP III, 2002).

Most patients had total cholesterol data in the range of borderline high $(200-239 \mathrm{mg} / \mathrm{dL})$ are $62 \%$ with an average of $223.77 \pm 49.69 \mathrm{mg} / \mathrm{dL}$, LDL in the borderline high range $(130-159 \mathrm{mg} / \mathrm{dL})$ and high $(160-189 \mathrm{mg} / \mathrm{dL})$ are $38 \%$ with an average of $152.59 \pm 44.25 \mathrm{mg} / \mathrm{dL}$, triglycerides in the optimal range $(<150 \mathrm{mg} / \mathrm{dl})$ are $54 \%$ with mean $200.85 \pm 101.53 \mathrm{mg} / \mathrm{dL}$, the patient's HDL level was mostly at the level of $>40 \mathrm{mg} / \mathrm{dL}(69 \%)$ with an average of $44.21 \pm 9.97 \mathrm{mg} / \mathrm{dL}$. Diabetes with dyslipemia is usually characterized by three conditions: high triglyceride concentrations, low HDL concentrations, and high small dense LDL concentrations (Chehade et al., 2013). The baseline HDL values of patients were different than in those where only $31 \%$ of patients had low HDL values $(<40 \mathrm{mg} / \mathrm{dL})$ (Table II).

It was found that after 6 weeks of treatment, there was a significant decrease in lipid profile (cholesterol, LDL, and TG) and VCAM-1 levels ( $p$ $<0,05$ ). These results are consistent with previous studies conducted by hogue et al., suggesting that the administration of atorvastatin $20 \mathrm{mg}$ for 6 weeks potentially altering lipid profile and also reduce inflammation (lowering CRP levels), oxidation (lowering levels of ox-LDL), and monocyte adhesion (Lowering levels of sICAM-1, sVCAM-1, sEselectin) in DM patients with hypertriglyceride (Hogue et al., 2008) (Table III).

Correlation test is conducted to know the relationship between lipid profile level and VCAM-1. VCAM-1 increase in DM patients has been reported in previous studies, which is related to the 
Table I. Baseline characteristic of patients

\begin{tabular}{|c|c|c|c|c|}
\hline \multirow{2}{*}{\multicolumn{2}{|c|}{ Patient Characteristics }} & \multicolumn{2}{|c|}{ Total Patients $(\mathrm{N}=13)$} & \multirow{2}{*}{$\overline{\mathrm{x}} \pm \mathrm{SD}$ (range) } \\
\hline & & $\mathbf{n}$ & $\%$ & \\
\hline \multirow[t]{2}{*}{ Gender } & Male & 6 & $46 \%$ & - \\
\hline & Female & 7 & $54 \%$ & - \\
\hline \multirow{3}{*}{ Age } & $36-45$ years & 1 & $8 \%$ & \\
\hline & $46-59$ years & 10 & $77 \%$ & $54.84 \pm 6.70$ \\
\hline & $60-74$ years & 2 & $15 \%$ & \\
\hline \multirow[t]{2}{*}{$\mathrm{HbA} 1 \mathrm{c}$} & $8-10 \%$ & 7 & $54 \%$ & \multirow{2}{*}{$10.75 \pm 1.68$} \\
\hline & $11-13 \%$ & 6 & $46 \%$ & \\
\hline \multirow{3}{*}{ BMI } & $18.5-24.9 \mathrm{~kg} / \mathrm{m}^{2}$ & 5 & $38 \%$ & \multirow{3}{*}{$26.79 \pm 5.11$} \\
\hline & $25.0-29.0 \mathrm{~kg} / \mathrm{m}^{2}$ & 6 & $46 \%$ & \\
\hline & $>30 \mathrm{~kg} / \mathrm{m}^{2}$ & 2 & $16 \%$ & \\
\hline \multirow[t]{2}{*}{ Comorbidities } & Hypertension & 3 & $23 \%$ & - \\
\hline & CHD & 2 & $15 \%$ & - \\
\hline
\end{tabular}

Table II. Baseline profil lipid pasien ( $\left.\mathrm{t}_{0}\right)$

\begin{tabular}{|c|c|c|c|c|c|}
\hline \multirow{2}{*}{\multicolumn{2}{|c|}{ Levels of Lipid Profile }} & \multicolumn{2}{|c|}{$\mathbf{t}_{\mathbf{0}}$} & \multicolumn{2}{|c|}{$\mathbf{t}_{1}$} \\
\hline & & $\mathbf{n}$ & $\%$ & $\mathbf{n}$ & $\%$ \\
\hline \multirow{4}{*}{ Total Cholesterol } & Desirable $(<200 \mathrm{mg} / \mathrm{dL})$ & 3 & $23 \%$ & 12 & $92 \%$ \\
\hline & Borderline High $(200-239 \mathrm{mg} / \mathrm{dL})$ & 8 & $62 \%$ & 1 & $8 \%$ \\
\hline & High $(\geq 240 \mathrm{mg} / \mathrm{dL})$ & 2 & $15 \%$ & - & - \\
\hline & Optimal $(<100 \mathrm{mg} / \mathrm{dL})$ & 1 & $8 \%$ & 9 & $69 \%$ \\
\hline \multirow{4}{*}{ LDL } & Near optimal $(100-129 \mathrm{mg} / \mathrm{dL})$ & 1 & $8 \%$ & 3 & $23 \%$ \\
\hline & Borderline high (130-159 mg/dL) & 5 & $38 \%$ & 1 & $8 \%$ \\
\hline & $\operatorname{High}(160-189 \mathrm{mg} / \mathrm{dL})$ & 5 & $38 \%$ & - & - \\
\hline & Very high $(\geq 190 \mathrm{mg} / \mathrm{dL})$ & 1 & $8 \%$ & - & . \\
\hline \multirow{4}{*}{ TG } & Optimal $(<150 \mathrm{mg} / \mathrm{dL})$ & 7 & $54 \%$ & 10 & $77 \%$ \\
\hline & Near optimal $(150-129 \mathrm{mg} / \mathrm{dL})$ & - & & - & \\
\hline & Borderline high $(200-499 \mathrm{mg} / \mathrm{dL})$ & 6 & $46 \%$ & 3 & $23 \%$ \\
\hline & $\operatorname{High}(\geq 500 \mathrm{mg} / \mathrm{dL})$ & - & & - & \\
\hline \multirow{2}{*}{ HDL } & $<40 \mathrm{mg} / \mathrm{dL}$ & 4 & $31 \%$ & 3 & $23 \%$ \\
\hline & $>40 \mathrm{mg} / \mathrm{dL}$ & 9 & $69 \%$ & 10 & $77 \%$ \\
\hline
\end{tabular}

Table III. Average changes in lipid profile and VCAM-1

\begin{tabular}{cccc}
\hline \multirow{2}{*}{ Lipid Profiles } & \multicolumn{2}{c}{ Mean \pm SD } & \multirow{2}{*}{$\mathbf{t}_{\mathbf{0}}$} \\
\cline { 2 - 4 } & $223.77 \pm 49.69(165-369)$ & $160.92 \pm 24.69(126-205)$ & 0.002 \\
Total Cholesterol & $152.59 \pm 44,25(79-266)$ & $93 \pm 21.44(60-136)$ & 0.001 \\
LDL & $200.85 \pm 101.53(103-377)$ & $123.30 \pm 62.77(68-246)$ & 0.016 \\
TG & $729.59 \pm 208.06$ & $675.06 \pm 182.88$ & 0.019 \\
VCAM-1 & & & \\
\hline
\end{tabular}

severity of atherosclerotic disease (Fasching et al., 1996). The result of correlation analysis between serum lipid profile level with serum VCAM-1 level (Figure 1, 2 and 3) showed no significant correlation $(p>0.05)$. Another study from Hubel et al found that VCAM- 1 correlated with LDL $(\mathrm{r}=0.50$, $\mathrm{P}<0.03$ ), but did not show any association with other lipid components (Hubel et al., 1998). While in the study in Indonesia showed only correlation in patients with type 2 diabetes showed a tendency of 


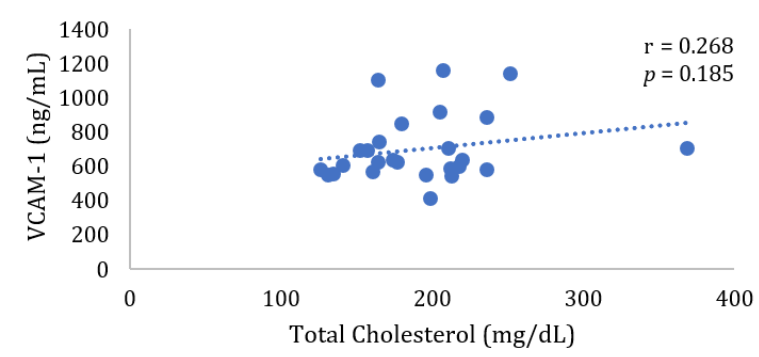

Figure 1. Correlation between total cholesterol and VCAM-1

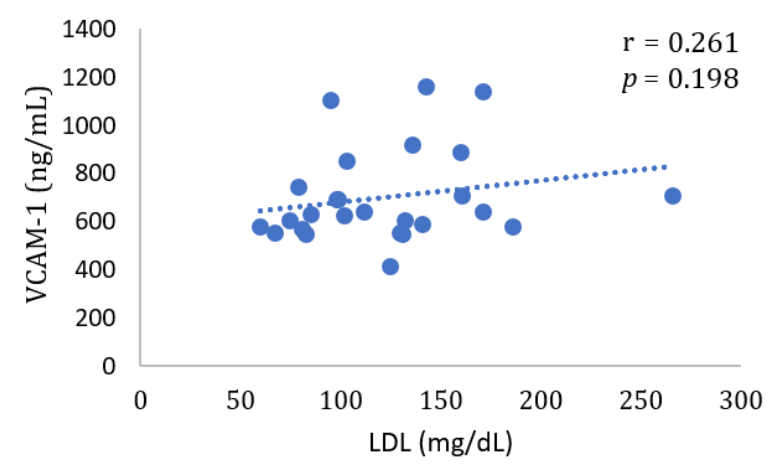

Figure 2. Correlation Between LDL and VCAM-1

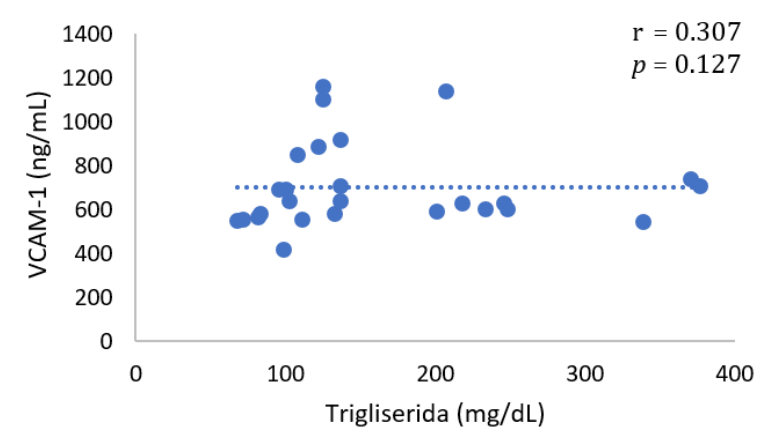

Figure 3. Correlation Between Trigliserida and VCAM-1

elevated plasma VCAM-1 levels along with the increase of albuminuria (Wibisono et al., 2012). The limitation of this study is the relatively small sample size (13 patients), and the variation of lipid profiles among patients is very large because it is influenced by many factor. This can cause statistical results that are not meaningful.

\section{CONCLUSION}

Atorvastatin therapy is able to improved atherogenic factors such as decreased lipid profile (total cholesterol, LDL, TG) and VCAM-1 inflammatory markers in DM patients with dyslipidemia, and no correlation between lipid profile (total cholesterol, LDL, TG) and VCAM -1.

\section{ACKNOWLEDGEMENT}

All of subjects are acknowledged for participating in this study. Sony Wibisono, DR. dr., SpPD, KEMD., FINASIM is acknowledgment for constructing comments in manuscript. The authors also thank you to members of Magister of Clinical Pharmacy, Airlangga University, Surabaya and private clinic of endocrine consultant in Surabaya. 


\section{REFERENCES}

Chehade JM., Gladysz M. and Mooradian AD., 2013. Dyslipidemia in Type 2 Diabetes : Prevalence, Pathophysiology, and Management. Drugs 73:327-339.

Fasching P, Veitl M, Rohac M, et al., 1996. Elevated concentrations of circulating adhesion molecules and their association with microvascular complications in insulindependent diabetes mellitus. Journal of Clinical Endocrinology and Metabolism ;81:4313-17.

George SJ., and Lyon C., 2010. Pathogenesis of Atherosclerosis, In : Atherosclerosis Molecular and Cellular Mechanisms. Weinheim : WILEY-VCH Verlag GmbH \& Co. KGaA, pp-3-14.

John MGB., Hegele RA., and Leiter LA., 2013. Dyslipidemia. Canadian Journal of Diabetes 37 : S110eS116.

Hogue JC., Lamarche B., Tremblay AJ., Bergeron J., Gagné C. and Couture P. 2008. Differential effect of atorvastatin and fenofibrate on plasma oxidized low-density lipoprotein, inflammation markers, and cell adhesion molecules in patients with type 2 diabetes mellitus. Metabolism Clinical and Experimental 57. 380 - 386.

Hubel CA., Fiona L., Lisa W., Robin E. Gandley; and James M. Roberts, 1998. Small Low-Density Lipoproteins and Vascular Cell Adhesion Molecule-1 Are Increased in Association With Hyperlipidemia in Preeclampsia. Metabolism. 47, No 10(October),1998:pp 1281-1288.

Lastra G., Syed S., Romayne LK., MD., and Camila M., James RS., 2014. Type 2 diabetes mellitus and hypertension: An update. Endocrinology and Metabolism Clinics of North America 2014 March ; 43(1): 103-122.

Malloy MJ. and John PK., 2012. Agents Used in Hyperlipidemia In : Basic \& Clinical Pharmacology 10th edition. USA : McGrawHill. pp. 625

Laurentia M., Soetrisno U. and Sidartawan Soegondo, 2014. Prevalence and clinical profile of diabetes mellitus in productive aged urban Indonesians. Journal of Diabetes Investigation 2014; 5: 507-512.

NCEP-expert-panel, third report of the National Cholesterol Education Program (NCEP) Expert Panel on Detection, Evaluation, and Treatment of High Blood Cholesterol in Adults (Adult Treatment Panel III) final report, Circulation 106 (2002) 314334210htawa, M., Masuda, N., Akasaka, I., et al., Cellular uptake of fluvastatin, an inhibitor of HMG-CoA reductase, by rat cultured hepatocytes and human aortic endothelial cells. British Journal of Clinical Pharmacology, 1999, 47:383-389.

Triplitt CL., Repas T. and Alvarez C., 2014. Diabetes Mellitus, In : Pharmacotherapy A Pathophysiologic Approach 9th edition. USA : McGraw Hill. pp 643-647

Huang W. and Yuqing ., 2010. Adhesion Molecules and Atherosclerosis, In : Atherosclerosis Molecular and Cellular Mechanisms. Weinheim : WILEY-VCH Verlag GmbH \& Co. KGaA, pp 43-55

Wibisono C., Fajar A., Tjokroprawiro A., Soetjahjo A., Pranoto A., Adi S. and Murtiwi S., 2012. Profil Albuminuria dan Kadar sVCAM-1 Pada Penderita Diabetes Melitus Tipe 2. Jurnal Penyakit Dalam Vol 13 Nomor 1 Januari. Hal 28-35. 